\title{
Rooting of hardwood cuttings of Roxo de Valinhos fig (Ficus carica L.) with different propagation strategies
}

\author{
Gilmar Antônio Nava ${ }^{1}$, Américo Wagner Júnior ${ }^{1}$, Eder Junior Mezalira², \\ Darcieli Aparecida Cassol ${ }^{3}$, Alexandre Luis Alegretti ${ }^{4}$ \\ http://dx.doi.org/10.1590/0034-737X201461060015
}

\begin{abstract}
The objective of this study was to evaluate the substrate, cuttings collection time, the position and the cutting depth, and the propagation environment on rooting of 'Purple Valinhos' fig tree cuttings in Southwestern Paraná, Brazil. Two experiments were carried out at UTFPR, Câmpus Dois Vizinhos, with hardwoods cuttings from Roxo de Valinhos fig tree. The first experiment used a randomized block design, in $3 \times 3 \times 2$ factorial (substrate $\mathrm{x}$ environment $\mathrm{x}$ collection time), with four replications of 10 cuttings per plot. The cuttings were collected in the first fifteen days of July and August. The substrates were sand, soil and the mixture of these [1:1 (v/v)]. The environments used were open sky, tunnel with plastic cover and tunnel with half-shade black net cover. The second experiment used a randomized block design, $2 \times 2 \times 3$ factorial (shoot cutting position $\times$ soil cover $\mathrm{x}$ shoot cutting depth), with four replications of 12 cuttings per plot. In the factor position, the vertically $\left(0^{\circ}\right.$ inclination) and inclined $\left(45^{\circ}\right.$ inclination $)$ shoot cuttings were evaluated. Soil cover was tested with mulching plastic cover or not. The tested depths were 1/3, $1 / 2$ and $2 / 3$ in relation to the total length of the shoot cutting. In both experiments, the following were analyzed: rooting and mortality indices, number of leaves and primary shoots, length of the three largest roots per cutting. It was conclude that, the protected environment with plastic cover on sand as substrate must recommended for the rooting of fig estaca, collecting them in the first half of July. The inclination position and cutting depth of the estaca and the substrate coverage with plastic mulching did not influence the results.
\end{abstract}

Key words: fig, vegetative propagation, environment condition, substrate.

\section{RESUMO}

\section{Enraizamento de estacas lenhosas de figueira (Ficus carica L.) cv. Roxo de Valinhos com diferentes estratégias de propagação}

O objetivo deste trabalho foi avaliar o substrato, a época de coleta das estacas, a posição e a profundidade da estaca e o ambiente de propagação para o enraizamento de estacas de figueira 'Roxo de Valinhos', no sudoeste do Paraná. Foram realizados dois experimentos, na UTFPR, Câmpus Dois Vizinhos, com estacas lenhosas de figueira cv. Roxo de Valinhos. O primeiro utilizou delineamento experimental em blocos ao acaso, em fatorial 3 × 3 × 2 (substrato $\mathrm{x}$ ambiente $\mathrm{x}$ época de coleta), com quatro repetições de 10 estacas por parcela. As estacas foram coletadas nas primeiras quinzenas de julho e agosto. Os substratos foram areia, solo e a mistura destes [1:1 (v/v)]. Os ambientes utilizados foram céu aberto, túnel baixo, com cobertura plástica, e túnel baixo, com tela de sombreamento de

Recebido para publicação em 18/12/2012 e aprovado em 23/04/2014.

${ }^{1}$ Agronomist, PhD. Universidade Tecnológica Federal do Paraná, Campus Dois Vizinhos, Estrada para Boa Esperança, Km 04, 85600-000, Caixa Postal 157, Dois Vizinhos, Paraná, Brazil. gilmarnava@utfpr.edu.br (corresponding author).

${ }^{2}$ Horticulture Technologist. Universidade Estadual do Oeste do Paraná, Campus Marechal Cândido Rondon, Rua Universitária, 2069, 85819-110, Cascavel, Paraná, Brazil. eder.mezzalira@gmail.com

${ }^{3}$ Horticulture Technologist. Universidade Tecnológica Federal do Paraná, Campus de Pato Branco, Estrada para Boa Esperança, Km 04, 85600-000, Caixa Postal 157, Dois Vizinhos, Paraná, Brazil. so_darci@ @otmail.com

${ }^{4}$ Forest Engineer Undergraduate Student. Universidade Tecnológica Federal do Paraná, Campus Dois Vizinhos, Estrada para Boa Esperança, Km 04, 85600-000, Caixa Postal 157, Dois Vizinhos, Paraná, Brazil. alexandreluisalegretti@ yahoo.com.br 
$50 \%$. O experimento 2 foi em blocos ao acaso, fatorial $2 \times 2 \times 3$ (posição da estaca x cobertura do solo x profundidade da estaca), com 4 repetições de 12 estacas por parcela. No fator posição avaliaram-se estacas na vertical $\left(0^{\circ}\right.$ de inclinação) e inclinadas ( $45^{\circ}$ de inclinação). No fator cobertura do solo, testou-se o uso, ou não, de cobertura plástica (mulching). As profundidades de enterrio das estacas foram de 1/3, 1/2 e 2/3 do seu comprimento total. Foram analisados, em ambos os experimentos, os índices de enraizamento e de mortalidade, o número de folhas e de brotos primários e o comprimento das três maiores raízes por estaca. Conclui-se que se deve usar ambiente protegido com filme plástico, sobre o leito de areia, no enraizamento das estacas de figueira, coletando-as na primeira quinzena de julho. A posição de inclinação e a profundidade da estaca, bem como a cobertura do substrato com mulching plástico não influenciaram os resultados.

Palavras-chave: figo, propagação vegetativa, condições ambientais, substrato.

\section{INTRODUCTION}

The fig tree (Ficus carica L.) was one of the fruit trees whose cultivation has evolved rapidly, from small orchards to commercial production, a fact that led Brazil to an important producer and exporter of figs (Torres, 1997). In 2012, Brazil produced 28,010 t of figs in an area of 2,925 ha (FAO, 2012; IBGE, 2012).

This fruit tree can be found in several regions of Brazil. The cultivar Roxo de Valinhos is about the only one commercially used because of its characteristics of high vigor, rusticity and productivity (Penteado, 1999). To be able to maintain the characteristics of genetic superiority and production in new orchards of fig, obtaining seedlings from asexual methods becomes necessary, since, if there is no mutation, the genetic material obtained is identical to the plant mother (Hartmann et al., 2002).

Among the asexual methods, cutting is the main one to be used for commercial propagation of fig in Brazil (Almeida \& Silveira, 1997) because it is efficient, presents low cost, uses one-year old hardwood cuttings, coming from winter pruning, and it does not require the use of irrigation with intermittent mist (Chalfun et al., 2002). For cutting of such fruit tree, cuttings with 1.5 to $3 \mathrm{~cm}$ in diameter and 30-40 $\mathrm{cm}$ in length, placed vertically in the planting hole, soon after collection, are used (Chalfun \& Hoffmann, 1997). In addition to the notillage planting in the hole, it can be propagated in beds or in plastic containers, the latter being the most widely used method in commercial nurseries.

However, when plastic containers or beds are used, it becomes necessary to use a substrate with features that provide the best conditions for the rapid, uniform and efficient rooting. The type of substrate to be used is an important factor to be regarded, as it influences directly on the success of rooting and cost of production of seedlings for the nursery or producer. According to Wendling et al. (2002), good substrate should have low density, good absorption capacity and water retention and aeration, allowing rapid drainage of excess of water, and be free of pests, diseases and toxic substances (Kämpf, 2000; Schmitz et al., 2002; Verdonck et al., 1981; Verdonck \& Gabriels, 1988).

Another factor to be considered for propagation of the fig tree is concerned to collection time of nursery material, since there may be variation in the $\mathrm{C} / \mathrm{N}$ relationship, and in the presence of rooting inhibitors, according to the season of the year. According to Fachinello et al. (2005), cuttings collected in the springsummer showed greater rooting capacity than those collected in the winter, which presented a higher degree of lignification and tend to root less. On the other hand, the amount of carbohydrate reserves in woody cuttings of temperate fruit trees is directly correlated with the rooting and survival indices of cuttings as auxins require a carbon source for the biosynthesis of nucleic acids and proteins (Hartmann et al., 2002).

For the environment for propagation of fig tree, the moisture of rooting environment should be controlled sine it can provide improved survival and rooting rates, according to its content (Pasqual et al. 2001) which should, preferably, take water-saturated environment, because until adventitious rootlets emergence, they do not have the capacity to absorb water. On the other hand, soil or substrate with an excess of water after the emergence of adventitious rootlets can lead to the rotting of the base of the fig tree cuttings. Therefore, this fact should be considered.

As previously observed, the cuttings have no capacity to absorb water until the emergence of adventitious rootlets, and together with humidity, the use of shade screens can be adopted. When working with fig tree cuttings collected in August, Souza (2008), found a 
greater percentage of rooting when environment with $30 \%$ of shade was used. Pio et al. (2003), when evaluating the greenhouse environments, shading with $50 \%$ of light and open sky and depths of burial of $1 / 3,2 /$ 3 and $3 / 3$ with fig tree cuttings, found that those totally buried presented the best rates of rooting and sprouting, regarding the greenhouse as the best propagation environment.

The objective of this study was to evaluate the substrate, the time for collecting the cuttings, the position and the depth of the cuttings and the propagation environment for the rooting of 'Roxo de Valinhos' fig tree cuttings in southwestern Paraná.

\section{MATERIAL AND METHODS}

Two experiments were carried at Seedling Production Nursery, Teaching and Research Unit (Unidade de Ensino and Pesquisa Viveiro de Produção de Mudas) at the Experimental Station of the Federal Technological University of Paraná (UTFPR), Campus Dois Vizinhos, State of Paraná, Brazil. The hardwood cuttings used in both experiments were obtained from pruned branches of fig tree (Ficus carica L.) cv. Roxo de Valinhos at ten years of age from the educational orchard of the referred institution.

Experiment 1 was arranged in a randomized block experimental design, using $3 \times 3 \times 2$ factorial design (substrate $\mathrm{x}$ rooting environment $\mathrm{x}$ cuttings collection time), with four replications of ten cuttings per experimental unit. The evaluated substrates were medium grain size sand (not washed and non-sterilized); soil collected from a typical Dystrophic Red Nitosol (EMBRAPACNPS, 2006) and the mixture of the two previous ones (1:1 v:v). The evaluated environments were open sky; low tunnel with $150-\mu \mathrm{m}$ transparent plastic cover and low tunnel with shade cloth cover 50\% transparent to light. The cuttings were collected in the first fortnights of July and August, 2008.

Leafless hardwood cuttings were prepared at an average size of $20 \mathrm{~cm}$ in length and $8 \mathrm{~mm}$ in diameter, with bevel cuts at the base, just below a bud and in crosssection at the upper end. After the pruning and the cuttings collection, they were buried in beds $(1.0 \mathrm{mx} 1.0 \mathrm{~m})$ with the pre-defined substrates and previously described, disposed inside the low tunnel. The physical structure of those tunnels were an arched rebar iron, coated with black hose, with ceiling height of about $1 \mathrm{~m}$ high, allowing air renovation and the removal of excessive heat, by their side openings.

After 81 days of experiment setting up, the following were evaluated: the percentages of rooted and dead cuttings, the number of leaves and primary buds, as well as the length of the three largest roots, according to the methodology proposed by Oliveira et al. (2008). Rooted cuttings were those that had at least one emerged root with length over $0.2 \mathrm{~cm}$.

The data of the analyzed variables were first submitted to analysis of variance and treatment means were compared by the Tukey's test $(p \leq 0.05)$. Data from rooting percentages and dead cuttings were previously transformed into arcsine $\sqrt{x / 100}$ and in in $\sqrt{x+1}$ for number of leaves. Other data did not undergo any changes.

In experiment 2 , it was used a randomized block design in a $2 \times 2 \times 3$ factorial design (cutting position $\mathrm{x}$ substrate cover $\mathrm{x}$ cutting burial depth), with 4 replications of 12 cuttings per experimental unit.

The cutting position factor consisted of the vertical levels $\left(0^{\circ}\right.$ inclination $)$ or inclined at $45^{\circ}$. Levels of substrate coverage factor were defined by the use of black plastic mulching, $150 \mu \mathrm{m}$ thick, or no plastic mulching (uncovered substrate). The depths of burial of the cuttings were $1 / 3,1 / 2$ and $2 / 3$ of its total length.

The cuttings with $20 \mathrm{~cm}$ in length and $8 \mathrm{~mm}$ in diameter were collected in the first fortnight of July, 2008 , by a bevel and perpendicular cut at the base and at the upper end of the cutting, respectively. Then, the cuttings were buried in the bed, with the substrate formed by the mixture of medium grain size unwashed and unsterilized sand: soil: average grain size vermiculite (2: 2: $1 \mathrm{v} / \mathrm{v} / \mathrm{v})$.

The evaluations carried out and the corresponding methods were the same as in Experiment 1.

\section{RESULTS AND DISCUSSION}

\section{Experiment 1}

It can be seen that the environment $x$ collection time interaction was significant for rooting percentage, number of leaves, length of the three largest roots and percentage of mortality of Roxo de Valinhos fig tree cuttings (Table 1). A significant interaction for substrate $\mathrm{x}$ collection time was also observed for the percentage of rooting, length of the three largest roots and percentage of dead cuttings (Table 2). Isolated significant effects were found for rooting and mortality percentages of the cuttings among the rooting environment factors (Table 1), substrate (Table 2) and percentage of rooting and mortality, number of leaves and length of the three longest roots, for the cuttings collection time factor.

On the other hand, no significant interactions between substrate $\mathrm{x}$ environment $\mathrm{x}$ collection time and substrate $\mathrm{x}$ environment were found for all variables analyzed (Tables 1 and 2).

A greater rooting (Tables 1 and 2) occurred when cuttings were collected at time 1 (first fortnight of July) 
compared with those collected at time 2 (first fortnight of August), regardless of the type of environment and substrate used. In Lavras, MG, Norberto et al. (2001) also found that the percentage of rooted cuttings decreased over the advance of cutting season, in which the months of April and May were those when the rooting percentage was higher (66\% without IBA and $95 \%$ with IBA).

It is assumed that the collection of cuttings at the time 1 (first fortnight of July) has favored rooting because they originated from dormant plants with higher accumulation of reserve substances (higher carbon/ nitrogen ratio - $\mathrm{C} / \mathrm{N})$. According to Fachinello et al. (2005), the high $\mathrm{C} / \mathrm{N}$ ratio induces a better rooting since auxin requires a carbon source for the biosynthesis of nucleic acids and proteins for the formation of adventitious roots.

At cuttings collection time 2 (first fortnight of August), the plants presented branches with buds at sprouting onset, leading to competition between new sprouts and rhizogenes for reserve substances and phytohormones, especially auxin, which may have favored for the lowest percentage of rooting.

However, at the time 2, the lowest percentage of dead cuttings was achieved (Table 2). Nevertheless, even with this increased survival, there was no conversion to formation of rootlets at this time, (Table 1), which does not configure this time as the best for rooting of the cuttings.

As for the type of environment, it was found that the cuttings maintained in bed with the use of low tunnel, covered with shade screen and plastic use presented the highest levels of rooting (Table 1). These data corroborate the level of rooting of cuttings of fig tree cv. Roxo de Valinhos obtained by Pio et al. (2003) in greenhouse environment. Pio et al. (2006) and Pio et al. (2008) stated that the greenhouse with plastic film, for asexual propagation of the fig tree, is the ideal

Table 1. Percentage of rooting, number of leaves per cutting, length of the three major roots of each stake and percentage of dead cuttings Roxo de Valinhos fig tree, according to the time of collection of cuttings and rooting environment. UTFPR, Dois Vizinhos, PR, 2011

\begin{tabular}{|c|c|c|c|c|}
\hline \multirow[b]{2}{*}{ Collection time } & \multicolumn{4}{|c|}{ Rooting percentage of the cuttings } \\
\hline & Open sky (no cover) & $\begin{array}{c}\text { Low tunnel with } \\
\text { plastic cover }\end{array}$ & $\begin{array}{c}\text { Low tunnel with } \\
\text { shading cover }\end{array}$ & Mean \\
\hline 1 & $22.77 \mathrm{a} \mathrm{B}^{*}$ & 38.49 a A & 44.84 a A & 35.37 \\
\hline 2 & $0.49 \mathrm{~b} \mathrm{~A}$ & $0.37 \mathrm{~b} \mathrm{~A}$ & $0.02 \mathrm{~b} \mathrm{~A}$ & 0.29 \\
\hline Mean & 11.63 & 19.43 & 22.43 & \\
\hline \multirow[t]{2}{*}{$\mathrm{CV}$} & \multicolumn{4}{|c|}{$35.19 \%$} \\
\hline & \multicolumn{4}{|c|}{ Number of leaves per cutting } \\
\hline Collection time & Open sky (ni cover) & $\begin{array}{c}\text { Low tunnel with } \\
\text { plastic cover }\end{array}$ & $\begin{array}{c}\text { Low tunnel with } \\
\text { shading cover }\end{array}$ & Mean \\
\hline 1 & 7.08 a A & 2.76 a B & $4.41 \mathrm{a} \mathrm{AB}$ & 4.75 \\
\hline 2 & $0.0 \mathrm{~b} \mathrm{~A}$ & $0.93 \mathrm{~b} \mathrm{~A}$ & $0.0 \mathrm{~b} \mathrm{~A}$ & 0.31 \\
\hline Mean & 3.54 & 1.85 & 2.21 & \\
\hline $\mathrm{CV}$ & \multicolumn{4}{|c|}{$35.63 \%$} \\
\hline
\end{tabular}

\begin{tabular}{lcccc}
\hline Colletion time & \multicolumn{4}{c}{ Length of the three longest root of each cutting } \\
\cline { 2 - 5 } & Open sky (no cover) & $\begin{array}{c}\text { Low tunnel with } \\
\text { plastic cover }\end{array}$ & $\begin{array}{c}\text { Low tunnel with } \\
\text { shading cover }\end{array}$ & Mean \\
\hline 1 & $5.0 \mathrm{a}$ A & 2.95 a AB & 2.79 a B & 3.58 \\
2 & $0.44 \mathrm{~b} \mathrm{~B}$ & $0.0 \mathrm{~b} \mathrm{~B}$ & $2.00 \mathrm{a} \mathrm{A}$ & 0.81 \\
Mean & 2.72 & 1.48 & 2.40 & \\
$\mathrm{CV}$ & & \multicolumn{2}{c}{$99.28 \%$} & \\
\hline
\end{tabular}

\begin{tabular}{|c|c|c|c|c|}
\hline \multirow[b]{2}{*}{ Collection time } & \multicolumn{4}{|c|}{ Percentage of dead cuttings } \\
\hline & Open sky (no cover) & $\begin{array}{l}\text { Low tunnel with } \\
\text { plastic cover }\end{array}$ & $\begin{array}{l}\text { Low tunnel with } \\
\text { shading cover }\end{array}$ & Mean \\
\hline 1 & 61.96 a A & $40.11 \mathrm{a} \mathrm{B}$ & 27.73 a C & 43.27 \\
\hline 2 & $0.0 \mathrm{~b} \mathrm{~A}$ & $0.0 \mathrm{~b} \mathrm{~A}$ & $0.0 \mathrm{~b} \mathrm{~A}$ & 0.0 \\
\hline Mean & 30.98 & 20.06 & 13.87 & \\
\hline $\mathrm{CV}$ & \multicolumn{4}{|c|}{$32.3 \%$} \\
\hline
\end{tabular}

${ }^{*}$ Means with different letters, lowercase letters in the same column and uppercase letters on the same row differ significantly at $5 \%$ of probability by the Tukey's test. Cutting collection time: 1- first fortnight of July; 2- first fortinight of August. 
environment for rooting since it provides a greater control of temperature and relative humidity, providing favorable conditions to cell division and differentiation.

The lowest rooting mean was obtained with cuttings kept in full sun (Table 1), assuming that this result occurs because cuttings had been more exposed to climate fluctuations conditions, resulting in greater dehydration, compared to those kept in protected environments (plastic film and shading cover), thus compromising the formation of rootlets. This fact was evidenced by the results obtained for mortality of cuttings, with the highest average found for those kept in full sun (Table 1).

According to Pasqual et al. (2001), moisture is one of the key external factors for rooting and survival. The need for water by cuttings to root is based on the fact that, immediately after placed on the substrate, they still do not present roots, therefore, they cannot absorb enough water to compensate transpiration and the growth of new shoots (Da Cunha et al., 2009). Thus, the environment for the cuttings must be saturated with water, avoiding sharp differences in water potential of the environment and cuttings, which results in water losses.

For the number of leaves per cuttings at time 1, the highest mean was obtained in uncovered environment, followed by low tunnel and shading coverage, in which the means did not differ significantly among each other.

At time 1, the use of uncovered bed also provided cuttings with longer roots, but it did not statistically differ from the low tunnel bed with plastic cover (Table 1). It is assumed that the fact of cuttings from the environment without coverage have more leaves and cuttings under plastic cover are in an environment with higher temperature compared to those under environment with shade screen cover, had as a consequence, a greater loss of water by transpiration by the cuttings of both environments. Thus, it is believed that the cuttings in these environments had demanded greater amount of photoassimlates for root development, searching for farther water to compensate for this greater loss.

It can be seen in Table 2 that the rooting of fig tree cuttings at the time 1 was statistically superior to the others, in which sand and sand + red latosol mixture was used, in relation to red latosol. Pio et al. (2008) also found that the mixture sand:soil favored the rooting of fig tree cuttings. Regarding time 2, there were no significant differences among substrates in as much as it was found no cutting rooting.

According to Barbosa \& Lopes (2007), rooting efficiency increases with the best aeration of the medium and no excessive retention of the moisture. Sand provides these features since it presents low water retention capacity, good drainage and aeration, being regarded as soil conditioner when used in mixtures as it improves the physical structure of the substrate. Thus, it is believed that the characteristics of sand described above provided the highest rooting means when used alone or mixed with soil.

The lower rooting of cuttings by using soil separately may be associated with a lower drainage capacity of water excess and, or to its compaction when submitted to frequent watering in the absence of a cover. Both factors reduce the oxygenation of the substrate and therefore reduce the capacity of emergence and growth of rootlets in the cuttings because oxygen is essential for the production of energy from their accumulated reserves.

For percentage of mortality of the cuttings at time 1, the mean values obtained with the evaluated substrates were statistically similar to each other, which did not occur at the time 2, since the sand led to higher losses. It is assumed that the greater loss of cuttings in sand at time 2 has occurred because less retention occurs in this substrate, needed for the survival of the cutting.

Table 2. Rooting percentage of root length of the three longest roots of Roxo Valinhos fig tree cuttings according to the substrate and rooting environment. UTFPR, Dois Vizinhos, PR, 2011

\begin{tabular}{lcccc}
\hline \multirow{2}{*}{ Collection time } & \multicolumn{4}{c}{ Rooting percentage of the cuttings } \\
\cline { 2 - 5 } & Sand & Soil & Sand + Soil & Mean \\
\hline 1 & $46.16 \mathrm{a} \mathrm{A}^{*}$ & $21.01 \mathrm{a} \mathrm{B}$ & $38.95 \mathrm{a} \mathrm{A}$ & 35.37 \\
2 & $0.87 \mathrm{~b} \mathrm{~A}$ & $0.00 \mathrm{~b} \mathrm{~A}$ & $0.00 \mathrm{~b} \mathrm{~A}$ & 0.29 \\
Mean & 23.52 & 10.51 & 19.48 & \\
CV & & $35.19 \%$ & \\
\hline
\end{tabular}

\begin{tabular}{lcccc}
\hline Collection time & \multicolumn{4}{c}{ Length of the three longest roots of the cuttings } \\
\cline { 2 - 5 } & Sand & Soil & Sand + soil & Sand \\
\hline 1 & $14.05 \mathrm{a} \mathrm{C}$ & $68.38 \mathrm{a} \mathrm{A}$ & $47.38 \mathrm{a} \mathrm{B}$ & 43.27 \\
2 & $0.0 \mathrm{~b} \mathrm{~A}$ & $0.0 \mathrm{~b} \mathrm{~A}$ & $0.0 \mathrm{~b} \mathrm{~A}$ & 0.0 \\
Mean & 7.03 & 34.19 & 23.69 & \\
CV & & & $32.30 \%$ & \\
\hline
\end{tabular}

*Means with different letters, lowercase letters in the same column and uppercase letters on the same row differ significantly at $5 \%$ of probability by the Tukey's test. Cutting collection time: 1- first fortnight of July; 2- first fortnight of August. 
As for the length of the three largest roots of the cuttings, the highest mean was obtained using latosol, which may be related to the greater availability of nutrients in relation to the sand, which is chemically inert.

\section{Experiment 2}

By analyzing the data in Tables 3 and 4, no significant effect was found for the factors analyzed separately as well as for their interactions, the percentage of rooted and dead cuttings, number of leaves per rooted cutting, average length of the three largest roots and total dry matter mass of the roots.

However, the number of buds per cutting was significant for the coverage factor, yielding the highest means by using black plastic mulching black as vegetation cover (Table 4). It is assumed that by using mulching increased temperature of the substrate and the microenvironment near the region of the cuttings, by the accumulated heat, which favored cell division, allowing obtaining more buds.

According to Fachinello et al. (2005), the rise in temperature promotes cell division and it may induce sprouting of buds before rooting, which is undesirable since it may impair the formation of adventitious roots because it reduces the amount of carbon sources required for this process. This phenomenon was observed in this study, in which sprout of cuttings with no formation of roots occurred.

However, it is important to note that even with the early budding of cuttings in relation to their roots, and because there were no statistical differences within and among the analyzed factors, it was possible to obtain rooting rates from $29 \%$ to $50 \%$ depending on the applied treatment. Nevertheless, Pio et al. (2003) found a higher percentage of rooting in cuttings of fig tree, cv. Roxo Valinhos (about $80 \%$ ), regardless of the environment

Table 3. Percentage of rooted or dead 'Roxo de Valinhos' fig tree cuttings, and number of buds and leaves per rooted cutting rooting under different rooting conditions.UTFPR, Dois Vizinhos, PR, 2011

\begin{tabular}{|c|c|c|c|c|c|c|c|c|}
\hline \multirow{3}{*}{$\begin{array}{l}\text { Cutting position / cutting } \\
\text { burial proportion }\end{array}$} & \multicolumn{6}{|c|}{ Cutting rooting percentage } & & \\
\hline & \multicolumn{4}{|c|}{ Covered substrate } & \multicolumn{4}{|c|}{ Uncovered substrate } \\
\hline & $1 / 3$ & $1 / 2$ & $2 / 3$ & Mean & $1 / 3$ & $1 / 2$ & $2 / 3$ & Mean \\
\hline Vertical & 40.53 & 29.16 & 37.50 & $35.73^{\text {ns* }}$ & 35.41 & 46.40 & 50.00 & $43.93^{\mathrm{ns}}$ \\
\hline Diagonal & 35.41 & 39.58 & 29.35 & 34.78 & 50.00 & 40.53 & 39.58 & 43.37 \\
\hline Mean & 37.97 ns & 34.37 & 33.42 & $35.26 \mathrm{~ns}^{* *}$ & $42.70^{\mathrm{ns}}$ & 43.46 & 44.79 & 43.65 \\
\hline $\mathrm{CV}$ & \multicolumn{8}{|c|}{$41.57 \%$} \\
\hline
\end{tabular}

\begin{tabular}{|c|c|c|c|c|c|c|c|c|}
\hline \multirow{3}{*}{$\begin{array}{l}\text { Cutting position / cutting } \\
\text { burial proportion }\end{array}$} & \multicolumn{8}{|c|}{ Dead cutting percentage } \\
\hline & \multicolumn{4}{|c|}{ Covered substrate } & \multicolumn{4}{|c|}{ Uncovered substrate } \\
\hline & $1 / 3$ & $1 / 2$ & $2 / 3$ & Mean & $1 / 3$ & $1 / 2$ & $2 / 3$ & Mean \\
\hline Vertical & 46.40 & 58.33 & 58.33 & $54.35^{\mathrm{ns}}$ & 58.33 & 45.26 & 41.66 & $48.41^{\text {ns }}$ \\
\hline Diagonal & 62.50 & 50.00 & 62.31 & 58.27 & 34.58 & 55.11 & 58.33 & 49.34 \\
\hline Média & $54.45^{\text {ns }}$ & 54.16 & 60.32 & $56.31(\mathrm{~ns})$ & $46.45^{\mathrm{ns}}$ & 50.18 & 50.00 & 48.88 \\
\hline $\mathrm{CV}$ & \multicolumn{8}{|c|}{$35.13 \%$} \\
\hline
\end{tabular}

\begin{tabular}{|c|c|c|c|c|c|c|c|c|}
\hline \multirow{3}{*}{$\begin{array}{l}\text { Cutting position / cutting } \\
\text { burial proportion }\end{array}$} & \multicolumn{8}{|c|}{ Average length of the three longest roots $(\mathrm{cm})$} \\
\hline & \multicolumn{4}{|c|}{ Covered substrate } & \multicolumn{4}{|c|}{ Uncovered substrate } \\
\hline & $1 / 3$ & $1 / 2$ & $2 / 3$ & Mean & $1 / 3$ & $1 / 2$ & $2 / 3$ & Mean \\
\hline Vertical & 10.29 & 8.44 & 12.31 & 1035 ns & 8.88 & 15.06 & 9,62 & $11,19^{\mathrm{ns}}$ \\
\hline Diagonal & 14.29 & 12.23 & 10.81 & 12.45 & 13.12 & 12.17 & 11,96 & 12,42 \\
\hline Mean & $12.29^{\mathrm{ns}}$ & 10.38 & 11.56 & $11.40^{\text {(ns) }}$ & $11.00^{\mathrm{ns}}$ & 13.61 & 10,79 & 11,80 \\
\hline $\mathrm{CV}$ & \multicolumn{8}{|c|}{$40.43 \%$} \\
\hline
\end{tabular}

\begin{tabular}{|c|c|c|c|c|c|c|c|c|}
\hline \multirow{3}{*}{$\begin{array}{l}\text { Cutting position / cutting } \\
\text { burial proportion }\end{array}$} & \multicolumn{8}{|c|}{ Root total dry mass $(\mathrm{g})-\mathrm{CV}=\mathbf{8 8 . 2 0 \%}$} \\
\hline & \multicolumn{4}{|c|}{ Covered substrate } & \multicolumn{4}{|c|}{ Uncovered substrate } \\
\hline & $1 / 3$ & $1 / 2$ & $2 / 3$ & Mean & $1 / 3$ & $1 / 2$ & $2 / 3$ & Mean \\
\hline Vertical & 1.43 & 1.14 & 0.63 & 1.07 ns & 0.41 & 1.92 & 1.44 & $1.26^{\mathrm{ns}}$ \\
\hline Diagonal & 1.02 & 1.20 & 0.55 & 0.93 & 1.25 & 1.14 & 1.05 & 1.15 \\
\hline Mean & $1.22 \mathrm{~ns}$ & 1.17 & 0.59 & $1.00^{(\mathrm{ns})}$ & $0.83^{\text {ns }}$ & 1.53 & 1.24 & 1.20 \\
\hline $\mathrm{CV}$ & $88.20 \%$ & & & & & & & \\
\hline
\end{tabular}

${ }^{* n \mathrm{n}}$ - not significant for the $\mathrm{F}$ test by comparing means of the levels within each factor alone; $* *$ ns: non-significant for the $\mathrm{F}$ test in the comparison among the means of substrate cover levels. 
Table 4. Number of buds and leaves per rooted cutting under diferente rooting conditions. UTFPR, Dois Vizinhos, PR, 2011

\begin{tabular}{|c|c|c|c|c|c|c|c|c|}
\hline \multirow{3}{*}{$\begin{array}{l}\text { Cutting position / cutting } \\
\text { burial proportion }\end{array}$} & \multicolumn{8}{|c|}{ Number of buds per rooted cutting } \\
\hline & \multicolumn{4}{|c|}{ Covered substrate } & \multicolumn{4}{|c|}{ Uncovered substrate } \\
\hline & $1 / 3$ & $1 / 2$ & $2 / 3$ & Mean & $1 / 3$ & $1 / 2$ & $2 / 3$ & Mean \\
\hline Vertical & 165 & 1.51 & 1.45 & $1.54^{\mathrm{ns}}$ & 1.35 & 1.37 & 1.19 & $1.31 \mathrm{~ns}$ \\
\hline Diagonal & 1.91 & 1.47 & 1.41 & 1.60 & 1.52 & 1.42 & 1.31 & 1.42 \\
\hline Média & $1.78^{\mathrm{ns}}$ & 1.49 & 1.43 & $1.57 \mathrm{~A}$ & $1.43^{\mathrm{ns}}$ & 1.39 & 1.25 & $1.36 \mathrm{~B}$ \\
\hline $\mathrm{CV}$ & \multicolumn{8}{|c|}{$22.71 \%$} \\
\hline
\end{tabular}

\begin{tabular}{|c|c|c|c|c|c|c|c|c|}
\hline \multirow{3}{*}{$\begin{array}{l}\text { Cutting position / cutting } \\
\text { burial proportion }\end{array}$} & \multicolumn{8}{|c|}{ Number of leaves per rooted cutting - CV $=34,79 \%$} \\
\hline & \multicolumn{4}{|c|}{ Covered substrate } & \multicolumn{4}{|c|}{ Unocovred substrate } \\
\hline & $1 / 3$ & $1 / 2$ & $2 / 3$ & Mean & $1 / 3$ & $1 / 2$ & $2 / 3$ & Mean \\
\hline Vertical & 7.63 & 6.56 & 7.97 & 7.39 ns & 6.24 & 8.05 & 6.69 & $7.00^{\mathrm{ns}}$ \\
\hline Diagonal & 8.93 & 7.84 & 6.85 & 7.88 & 8.58 & 7.43 & 7.00 & 7.68 \\
\hline Mean & 8.28 ns & 7.20 & 7.41 & $7.63^{\text {(ns) }}$ & $7.41^{\mathrm{ns}}$ & 7.74 & 6.84 & 7.34 \\
\hline $\mathrm{CV}$ & \multicolumn{8}{|c|}{$34.79 \%$} \\
\hline
\end{tabular}

ns: non-significant for the F test when comparing means of the levels within each factor alone; ${ }^{\text {(ns): }}$ non-significant for the F test when comparing means of substrate cover levels. Means followed by different upper case letters on the line differ statistically by the Tukey's test at 5\% of error probability.

used when they were completely buried (3/3), compared with those at $1 / 3$ and $2 / 3$, using the mixtures of soil:sand $(2: 1 \mathrm{v} / \mathrm{v})$ as substrate in three environments (full sun, screen and greenhouse). Differences between the results achieved in this work and of those in this study can be attributed to the type of cutting and environment used for its rooting.

The highest mean values of adventitious rooting obtained in this study were $35.37 \%$ (Tables 1 and 2) and about $43.5 \%$ (Table 3), when cuttings were collected in July and different environments and substrates were tested as well as different positions and depths of cutting burial, respectively. Using IBA at a concentration of 2000 mg L ${ }^{-1}$, Pio et al. (2006) obtained $56.67 \%$ of rooting of apical hardwood cuttings of fig tree, collected in August, in Lavras, MG. Norberto et al. (2001) also obtained rooting rates of 'Roxo de Valinhos' fig tree cuttings higher than those obtained in this study, when $100 \mathrm{mg} \mathrm{L}$ ${ }^{1}$ IBA were used. Thus, this factor, together with management strategies of plants, favoring the accumulation of carbohydrates and auxins, deserves attention in further studies aimed at increasing the rooting rates of hardwood cuttings, to reduce costs and delays in the implementation of new fig tree orchards.

\section{CONCLUSIONS}

The environment influences the rooting process of fig tree cuttings. In addition, the use of protected environment with transparent plastic film is recommended.

The collection of fig tree cuttings for rooting should be held in the first fortnight of July in the southwestern Paraná.
Among the evaluated substrates, medium grain size sand was the best.

The rooting of 'Roxo de Valinhos' fig tree cuttings do not rely on its position, depth and substrate cover.

\section{REFERENCES}

Almeida MM \& Silveira ET (1997) Tratos culturais na cultura da figueira no Sudoeste de Minas Gerais. Informe Agropecuário, 18:27-33.

Barbosa JG \& Lopes LC (2007) Propagação de plantas ornamentais. Viçosa, UFV. 183p.

Chalfun NNJ \& Hoffmann A (1997) Propagação da figueira. Informe Agropecuário, 18:09-13.

Chalfun NNJ, Abrahão E, Alvarenga AA, Regina MA \& Pio R (2002) Poda e condução da figueira. Lavras, UFLA. 12p. (Boletim de extensão, 104).

Da Cunha ACM, Nogueira HP, Garcia LH, Barros FN \& Palha FL (2009) Relações entre variáveis climáticas com produção e enraizamento de miniestacas de eucalipto. Revista Árvore, 33:195-203.

Embrapa - Centro Nacional de Pesquisa de Solos (2006) Sistema Brasileiro de Classificação de Solos. $2^{\mathrm{a}}$ ed. Rio de Janeiro, Embrapa Solos. 412p.

Fachinello JC, Hoffmann A \& Nachtigal JC (2005) Propagação de plantas frutíferas. Brasília, Embrapa Informação Tecnológica. 221p.

FAO (2012) Figs Production, 2012. Disponível em: <http://faostat.fao.org/ site/567/DesktopDefault.aspx?PageID=567\#ancor $>$. Acessado em: 11 de dezembro de 2014.

Hartmann HT, Kester DE, Davies Junior FT \& Geneve RL (2002) Plant propagation: principles and practices. $7^{\mathrm{a}} \mathrm{ed}$. New Jersey, Prentice Hall. $880 \mathrm{p}$.

IBGE (2012) Sistema IBGE de Recuperação Automática - SIDRA. Área colhida e quantidade produzida de figos no Brasil em 2012. Disponível em: <http://www.sidra.ibge.gov.br/bda/tabela/ protabl.asp? $\mathrm{c}=1613 \& \mathrm{z}=\mathrm{t} \& \mathrm{o}=11 \& \mathrm{i}=\mathrm{P}>$. Acessado em: $11 \mathrm{de}$ dezembro de 2014.

Kämpf AN 2000 Seleção de materiais para uso como substrato. In: Kämpf AN, Fermino MH (Eds.) Substrato para plantas: a base da produção vegetal em recipientes. Porto Alegre, Gênesis. 139-145.

Rev. Ceres, Viçosa, v. 61, n.6, p. 989-996, nov/dez, 2014 
Norberto PM, Chalfun NNJ, Pasqual M, Veiga RD, Pereira GE \& Mota JH (2001) Efeito da época de estaquia e do AIB no enraizamento de estacas de figueira (Ficus carica L.). Ciência e Agrotecnologia, 25:533541.

Oliveira Y, Silva ALL, Pinto F, Quoirin M \& Biasi LA(2008) Comprimento das estacas no enraizamento de melaleuca. Scientia Agrária, 9:415418.

Pasqual M, Chalfun NNJ \& Ramos JD (2001) Fruticultura comercial Propagação de plantas frutíferas. Lavras, UFLA/FAEPE. 137p.

Penteado SR O cultivo da figueira no Brasil e no mundo. In: Corrêa LS de \& Boliani A C (1999) (Eds.) Cultura da figueira: do plantio à comercialização. Ilha Solteira, FAPESP. 1-16.

Pio R, Dalastra IM, Campagnolo MA \& Celant VM (2008) Diferentes substratos, ambiente e presença da gema apical no enraizamento de estacas de figueira. Scientia Agraria, 9:463-467.

Pio R, Gontijo TCA, Carrijo EP, Visioli EL, Tomasetto F, Chalfun NNJ \& Ramos JD (2003) Enraizamento de estacas apicais de figueira em diferentes acondicionamentos e ambientes distintos. Revista Brasileira de Agrociência, 9:357-360.
Pio R, Ramos JD, Chalfun NNJ, Gontijo TCA, Mendonça V, Carrijo EP \& Chagas EA (2006) Propagação de estacas apicais de figueira: diferentes ambientes, ácido indolbutírico e tipo de estaca. Ciência e Agrotecnologia, 30:1021-1026.

Schmitz JAK, Souza PVD \& Kämpf AN (2002) Propriedades químicas e físicas de substratos de origem mineral e orgânica para o cultivo de mudas em recipientes. Ciência Rural, 32:937-944.

Souza CSS (2008) Estudo de ambientes de enraizamento, tempo de imersão em AIB, estratificação a frio e enxertia de mesa na figueira. Tese de Doutorado. Universidade Estadual Paulista, Ilha Solteira. $101 \mathrm{p}$

Verdonck O, Vleeschaumer D \& De Boodt M (1981) The influence of the substrate to plant growth. Acta Horticulturae, 150:467-473.

Verdonck O \& Gabriels R (1988) Substrate requirements for plants. Acta Horticulturae, 221:19-23.

Wedling I, Gatto A \& Paiva HN (2002) Substratos, adubação e irrigação na produção de mudas. Viçosa, Aprenda Fácil. 166p. 